\title{
Biomass spectra in benthic fish assemblages in the Benguela System
}

\author{
Enrique Macpherson*, Ana Gordoa \\ Centro de Estudios Avanzados de Blanes (CSIC), Cami de Santa Bárbara s/n, E-17300 Blanes (Girona), Spain
}

\begin{abstract}
Biomass spectra in the different benthic fish assemblages at depths between 100 and $800 \mathrm{~m}$ off the coast of Namibia were studied over a period of $3 \mathrm{yr}$ These assemblages were located in areas spanning active upwelling centres on the shelf and zones of lower productivity on the lower slope. The slopes of the curves for the normalized size distributions were related to zonal productivity and abundance of the smallest size classes. In the main upwelling centre, in which abundance of small specimens was higher and community diversity lower, biomass clearly dropped off with increasing size; teleost fishes and mid-level predators (which prey on euphausiids and other pelagic crustaceans) predominated. In the less productive zone, where the biomass of small specimens was very low and community diversity very high, biomass increased or at least tended to remain constant with size and elasmobranchs and apex predators (which prey on fish and cephalopods) were most abundant.
\end{abstract}

KEY WORDS: Biomass spectra $\cdot$ Fish $\cdot$ Benguela system $\cdot$ SE Atlantic

\section{INTRODUCTION}

Size distributions are a topic of much ecological interest for all types of communities (Margalef 1981, Peters 1983). They contain latent information on community metabolism not furnished by variables measured in conventional studies, and examination of size distributions may afford an alternative to population-based approaches, including fisheries management (Sheldon et al. 1977, Moloney \& Field 1985, Rasmussen 1993).

In aquatic systems, studies of this kind have mainly been carried out on very small organisms (e.g. bacteria, phytoplankton, meiofauna) and have been more sporadic in the case of the macrofauna and fishes (e.g. Sheldon et al. 1972, Platt \& Denman 1978, Schwinghammer 1981, Warwick 1984, Haedrich 1986, Rodríguez \& Mullin 1986, Sprules \& Munawar 1986, Haedrich \& Merret 1992, Cattaneo 1993, Rasmussen 1993, Rodhouse et al. 1994, Thurston et al. 1994).

Biomass spectra follow different trends, e.g. uniform biomass across logarithmic size categories (Sheldon et al. 1972) or marked peaks and troughs (Schwingham-

•E-mail: macpherson@ceab.es mer 1981, Warwick 1984) that have sometimes been linked to system productivity and stability (Sprules \& Munawar 1986, Rasmussen 1993, Rojo \& Rodríguez 1994), though findings have been contradictory. Unfortunately, this type of study is still uncommon; in addition, such studies have on occasion been insufficiently robust statistically and have seldom been replicated over space and time (Gaedke 1992, Quiñones 1994), which has led to too much speculation regarding the results and has lessened the reliability of the conclusions that have been drawn (Ahrens \& Peters 1991, Rasmussen 1993. Thiebaux \& Dickie 1993, Rodríguez 1994).

The present paper analyses the biomass spectra in benthic fish assemblages on the continental shelf and slope off southern Namibia (Southeast Atlantic). These assemblages encompass over 90 species (Macpherson 1989 ) and were sampled intensively in 2 different seasons over a period of $3 \mathrm{yr}$. The study area is characterized by active upwelling along the continental shelf, resulting in some of the world's most productive grounds (Shannon 1985). Changes in hydrographic conditions and productivity related to upwelling are clear causal factors underlying the distributions of several fish assemblages (Mas-Riera et al. 1990). Both the 
features of the study area and the extensive sampling programme provide an adequate basis for studying biomass spectral patterns in the different fish assemblages and the relationship of these patterns to productivity in the area.

\section{MATERIALS AND METHODS}

The data examined here were collected in the Southeast Atlantic Ocean off southern Namibia $\left(23^{\circ}\right.$ to $29^{\circ} 30^{\prime} \mathrm{S}$. Productivity in the region is very high along the continental shelf $(<300 \mathrm{~m})$, especially north of $28^{\circ} \mathrm{S}$ (Shannon 1985, Estrada \& Marrase 1987), which gives rise to large expanses of bottom waters with very low levels of dissolved oxygen (Chapman \& Shannon 1985).

Over 90 demersal fish species are found in the study area (Macpherson 1989). These species can be clearly divided by biogeographic boundaries into 4 species assemblages located on the continental shelf (ca 100 to $300 \mathrm{~m}$ ) and upper slope (ca 300 to $500 \mathrm{~m}$ ), separated by the shelf break (ca $300 \mathrm{~m}$ isobath) and by latitude (ca $28^{\circ}$ S) (Mas-Riera et al. 1990, Macpherson \& Gordoa 1992). A fifth assemblage is located on the lower slope (ca 500 to $800 \mathrm{~m}$ ) (Turon 1986, Macpherson 1989). The assemblages situated on the continental shelf inhabit the most productive areas, whereas the assemblage located on the lower slope occupies the poorest (Chapman \& Shannon 1985, Estrada \& Marrase 1987 ). Diversity in the northern shelf assemblage (23 to $28^{\circ} \mathrm{S}, 100$ to $300 \mathrm{~m}$ ) is lower than in the others, because upwelling is more intense in that area and dissolved oxygen levels at the bottom are very low (MasRiera et al. 1990). The northern, upper slope assemblage (23 to $28^{\circ} \mathrm{S}, 300$ to $500 \mathrm{~m}$ ) encompasses areas where fishing pressure is high. Fishing (bottom trawl) activity was particularly intense north of $28^{\circ} \mathrm{S}$ latitude, mainly between 250 and $400 \mathrm{~m}$ (Gordoa et al. 1995). In contrast, the assemblages located south of that latitude or inshore are subject to negligible levels of fishing pressure, because the bottoms are not conducive to trawling or are of little interest to commercial fisheries (Gordoa et al. 1985)

Fish samples were collected in the course of 6 stratified random bottom-trawl surveys carried out during 3 consecutive austral winters (1987/88/89) and summers (1988/89/90). Over 70 stations spanning depths between 100 and $500 \mathrm{~m}$ were occupied during each survey. On 3 cruises (winter 1988 and summer 1989 and 1990), depths between 500 and $800 \mathrm{~m}$ were sampled as well. The survey procedure was described by Macpherson \& Gordoa (1992). The number of specimens and size frequencies were compiled for each species at each station, and a minimum of 40000 specimens were measured per cruise using an electronic ichthyometer (MCV Co.). Length units were converted to weight using available weight-length relationships. The size range was from 15 to $120 \mathrm{~cm}$; the smaller size classes were probably underrepresented in the samples, while the larger size classes were extremely scarce. Species biomass by size class for each assemblage was estimated following standard fisheries methodologies (e.g. Doubleday \& Rivard 1981, Payne et al. 1985).

Normalized biomass spectra (NBSs) were calculated by regressing the logarithm of the mean biomass by size class divided by the weight range of the interval against the logarithm of the upper limit of the size class (see also Platt \& Denman 1978, Sprules \& Munawar 1986). Accordingly, a slope for a normalized size distribution equal to -1 was indicative of a tendency for biomass to remain constant over the size spectrum; a slope shallower than - 1 was indicative of increasing biomass with size; and a slope steeper than -1 was indicative of decreasing biomass with size.

The regressions were performed separately for each of the 5 fish assemblages: northern shelf (ca $23^{\circ} 00$ to $27^{\circ} 59^{\prime} \mathrm{S}, 100$ to $299 \mathrm{~m}$ ); northern upper slope (ca $23^{\circ} 00^{\prime}$ to $27^{\circ} 59^{\prime} \mathrm{S}, 300$ to $499 \mathrm{~m}$ ); southern shelf (ca $28^{\circ}$ to $29^{\circ} 30^{\prime} \mathrm{S}, 100$ to $299 \mathrm{~m}$ ); southern upper slope (ca $28^{\circ}$ to $29^{\circ} 30^{\prime} \mathrm{S}, 300$ to $499 \mathrm{~m}$ ); and lower slope (ca $23^{\circ} 00^{\prime}$ to $29^{\circ} 30^{\prime} \mathrm{S}, 500$ to $800 \mathrm{~m}$ ). The 5 assemblages are permanent entities, but the geographic boundaries for each assemblage differed slightly between surveys according to seasons and years and the intensity of upwelling (Mas-Riera et al. 1990, Macpherson \& Gordoa 1992) and hence were calculated separately for each cruise.

The Shannon-Weaver diversity index was calculated for each assemblage on each cruise using species abundance in number. In addition, species were classified by (1) the existing 2 major taxonomic groupings and (2) trophic groupings. Accordingly, in Case 1 species were divided into elasmobranchs and teleost fishes, which follow quite different patterns of reproduction and recruitment in that elasmobranchs usually produce small numbers of juveniles each year, whereas teleosts usually have higher rates of recruitment (e.g. Merrett 1994). In Case 2 the species or the various size classes within those species that undergo ontogenetic changes in their diet were divided into 5 groupings, according to main prey type (Macpherson 1989 and references therein). The 5 groupings were: pelagic crustacean predators (PCP); myctophid and pelagic cephalopod predators (MCP); polychaete predators (PP); benthic crustacean predators (BCP); and benthic fish predators (BFP). Since pelagic crustaceans and polychaetes are preyed upon by cephalopods, myctophids, and other fishes, the MCP and BFP groupings are commonly regarded as occupying higher 
trophic levels than the other trophic groupings. Our results have been expressed as the percentage contribution of each grouping to the total biomass of each assemblage. Trophic groupings were only established for the 3 cruises that spanned all 5 assemblages (winter 1988 and summer 1989 and 1990).

\section{RESULTS}

Table 1 shows the results for the normalized size distributions for the 5 assemblages from the different surveys. The regressions for the assemblages on the continental shelf and upper slope explained a substantial proportion of the variance, and the $r^{2}$ values were mostly greater than 0.85 ; on the lower slope the values were somewhat lower $\left(r^{2}=0.53\right.$ to 0.62$)$.

The slopes for most of the curves for the assemblages on the continental shelf and upper slope were steeper than -1 , indicating that the biomass was not distributed uniformly over the different size classes (slope equal to -1 ) but rather decreased with size. The slope for the northern shelf assemblage, located in the region of highest productivity, was in all cases steeper than the slopes for the other assemblages. In contrast, the values of the slopes for the southern shelf assemblage and the upper slope assemblages did not follow a distinct pattern; these slopes usually were clearly steeper than -1 , but sometimes the difference was not statistically significant. The slopes for the lower slope assemblage were shallower than or equal to -1 , indicating that biomass increased with size or at least tended to remain constant across the size classes. No appreciable differences were observed between assemblages subjected to high (northern upper slope assemblage) and low (e.g. southern upper slope assemblage) levels of fishing pressure.

The slopes of the curves exhibited a clear relationship to the biomass of the smallest size class (Table 1). The biomass of the smallest individuals was greatest in those cases in which the slopes were steepest and productivity highest (northern shelf assemblage). The lowest biomass values in the smallest size classes were recorded in those cases in which the slopes of the curves were flattest and productivity lowest (lower slope assemblage).
The diversity index was lowest for the assemblage located in the region of maximum upwelling and was higher for the upper slope and southern shelf assemblages. Diversity index values were highest for the lower slope assemblage.

The proportions of elasmobranchs and teleost fishes differed distinctly from zone to zone. The proportion of elasmobranchs did not usually exceed $10 \%$ of the total biomass in the shelf and upper slope assemblages but was in all cases greater than $50 \%$ in the lower slope assemblage (Table 1).

The PCP grouping predominated ( $>82.6 \%)$ in the assemblage located in the area of peak upwelling (northern shelf assemblage). That same grouping also predominated in the southern shelf assemblage,
Table 1 Descriptive statistics for the biomass spectra by survey and assemblage considered. Assemblages: NSh = northern shelf; NUS = northern upper slope; SSh = southern shelf; SUS = southern upper slope; LS = lower slope. BMS = normalized biomass in the smallest size classes; $H^{\prime}=$ ShannonWeaver diversity index based on the total number of individuals for each species; \% Tel = percentage of teleost fishes in the total biomass; \% Elasm = percentage of elasmobranchs in the total biomass. $p<0.05$ in all cases

\begin{tabular}{|c|c|c|c|c|c|c|c|c|}
\hline & $\mathrm{r}^{2}$ & $a$ & $b$ & SE & BMS & $H^{T}$ & "ivel & $\%$ Elasm \\
\hline \multicolumn{9}{|c|}{ Winter 1987} \\
\hline NSh & 0.98 & 29.28 & -1.90 & 0.11 & 16.14 & 1.19 & 99.1 & 0.9 \\
\hline NUS & 0.94 & 27.36 & -1.77 & 0.19 & 14.35 & 1.25 & 93.1 & 6.9 \\
\hline SSh & 0.92 & 27.53 & -1.76 & 0.22 & 14.46 & 2.88 & 92.3 & 7.7 \\
\hline SUS & 0.88 & 8.41 & -1.43 & 0.49 & 12.11 & 1.56 & 86.2 & 13.8 \\
\hline \multicolumn{9}{|c|}{ Summer 1988} \\
\hline NSh & 0.95 & 32.80 & -2.27 & 0.23 & 16.83 & 1.14 & 97.8 & 2.2 \\
\hline NUS & 0.80 & 19.15 & -0.76 & 0.16 & 12.93 & 2.70 & 64.4 & 35.6 \\
\hline SSh & 0.79 & 24.10 & -1.36 & 0.34 & 13.21 & 1.95 & 90.1 & 9.1 \\
\hline SUS & 0.97 & 22.20 & -1.15 & 0.08 & 14.58 & 2.32 & 90.0 & 10.0 \\
\hline \multicolumn{9}{|c|}{ Winter 1988} \\
\hline NSh & 0.89 & 36.91 & -2.81 & 0.49 & 15.55 & 1.45 & 99.5 & 0.5 \\
\hline NUS & 0.86 & 24.94 & -1.43 & 0.43 & 13.20 & 2.23 & 83.9 & 16.1 \\
\hline SSh & 0.78 & 28.68 & -1.85 & 0.24 & 15.16 & 1.47 & 96.3 & 3.7 \\
\hline SUS & 0.95 & 25.25 & -1.34 & 0.12 & 15.69 & 1.77 & 95.1 & 4.9 \\
\hline LS & 0.53 & 11.19 & -0.52 & 0.22 & 6.97 & 4.04 & 30.6 & 69.4 \\
\hline \multicolumn{9}{|c|}{ Summer 1989} \\
\hline NSh & 0.89 & 31.40 & -2.00 & 0.31 & 15.85 & 1.49 & 99.4 & 0.6 \\
\hline NUS & 0.91 & 25.54 & -1.35 & 0.21 & 15.31 & 2.59 & 75.2 & 24.8 \\
\hline SSh & 0.88 & 26.16 & -1.60 & 0.30 & 13.74 & 2.14 & 88.2 & 11.8 \\
\hline SUS & 0.93 & 29.53 & -2.00 & 0.25 & 14.80 & 2.13 & 94.1 & 5.9 \\
\hline LS & 0.58 & 9.72 & -0.32 & 0.13 & 7.76 & 3.51 & 30.4 & 69.6 \\
\hline \multicolumn{9}{|c|}{ Winter 1989} \\
\hline NSh & 0.97 & 30.60 & -2.15 & 0.16 & 15.83 & 1.66 & 99.7 & 0.3 \\
\hline NUS & 0.64 & 21.11 & -1.10 & 0.36 & 11.20 & 2.17 & 55.4 & 44.6 \\
\hline SSh & 0.93 & 25.87 & -1.73 & 0.23 & 12.87 & 1.94 & 99.1 & 0.9 \\
\hline SUS & 0.91 & 28.41 & -1.84 & 0.22 & 14.07 & 1.33 & 98.7 & 1.3 \\
\hline \multicolumn{9}{|c|}{ Summer 1990} \\
\hline NSh & 0.99 & 37.29 & -2.69 & 0.68 & 18.77 & 1.46 & 99.8 & 0.2 \\
\hline NUS & 0.90 & 28.46 & -1.85 & 0.27 & 14.09 & 0.93 & 92.8 & 7.2 \\
\hline SSh & 0.81 & 21.23 & -0.97 & 0.23 & 15.20 & 1.91 & 96.3 & 3.7 \\
\hline SUS & 0.87 & 22.52 & -1.37 & 0.24 & 11.97 & 2.30 & 95.1 & 4.9 \\
\hline LS & 0.62 & 15.50 & -0.99 & 0.34 & 7.66 & 5.54 & 43.0 & 57.0 \\
\hline
\end{tabular}


Table 2. Percentage contribution to the total biomass by the different trophic groupings, by survey and assemblage. PCP = pelagic crustacean predators; $\mathrm{MCP}=$ myctophid and pelagıc cephalopod predators; $\mathrm{PP}=$ polychaete predators $\mathrm{BCP}=$ benthic crustacean predators; BFP = benthic fish predators. Assemblage designations same as in Table 1

\begin{tabular}{|c|c|c|c|c|c|}
\hline & \multicolumn{5}{|c|}{ Assemblage } \\
\hline & NSh & NUS & SSh & SUS & LS \\
\hline \multicolumn{6}{|c|}{ Winter 1988} \\
\hline PCP & 88.7 & 2.3 & 69.3 & 36.2 & 5.7 \\
\hline MCP & 4.5 & 58.7 & 9.6 & 37.7 & 59.5 \\
\hline PP & 4.3 & 28.7 & 2.1 & 8.9 & 6.7 \\
\hline $\mathrm{BCP}$ & 0.7 & 4.7 & 8.6 & 6.5 & 18.6 \\
\hline BFP & 1.2 & 5.6 & 6.5 & 10.6 & 9.6 \\
\hline \multicolumn{6}{|c|}{ Summer 1989} \\
\hline PCP & 94.0 & 1.9 & 55.6 & 24.5 & 3.8 \\
\hline $\mathrm{MCP}$ & 4.8 & 48.2 & 11.6 & 30.1 & 57.4 \\
\hline PP & 0.7 & 36.7 & 10.8 & 15.5 & 5.1 \\
\hline BCP & 0.3 & 6.0 & 9.6 & 10.4 & 19.2 \\
\hline BFP & 0.2 & 7.2 & 124 & 19.5 & 14.5 \\
\hline \multicolumn{6}{|c|}{ Summer 1990} \\
\hline PCP & 82.6 & 10.2 & 81.0 & 29.9 & 2.6 \\
\hline $\mathrm{MCP}$ & 4.0 & 62.7 & 11.2 & 35.0 & 61.7 \\
\hline PP & 5.2 & 20.3 & 2.3 & 12.6 & 7.2 \\
\hline $\mathrm{BCP}$ & 4.6 & 5.2 & 2.6 & 8.9 & 16.9 \\
\hline BFP & 3.6 & 2.1 & 2.9 & 13.5 & 11.6 \\
\hline
\end{tabular}

though the percentage values were lower 155.6 to $81.0 \%$ ). The MCP grouping predominated in the 2 upper slope assemblages, especially in the northern upper slope assemblage, and the PP grouping was also well represented in those assemblages. The MCP, $\mathrm{BCP}$, and BFP groupings predominated in the least productive zone (lower slope) (Table 2).

\section{DISCUSSION}

The results of this study show that the biomass spectra for the different assemblages followed clearly defined patterns that persisted over the different seasons and years. The fitted biomass spectra explained a considerable portion of the variance in the data, and hence those patterns clearly point up gross differences in the size compositions of the assemblages.

The different size spectra observed in this study may have been influenced by fishing activity, particularly heavy on the northern upper slope, though there was no evidence of any such effect. While fisheries normally remove biomass over certain size ranges, thereby altering undisturbed size spectra, no differences in the NBSs were observed among the fish assemblages considered here for areas with differing levels of fishing pressure. It thus seems likely that trawl fishing activities in this area harvest over the entire spectrum of size classes, and there is evidence that fishing has not changed either the structure of the assemblages considered (Macpherson \& Gordoa 1992 ) or the size structures of the 40 most abundant demersal fish species (Gordoa \& Duarte 1992). The latter authors found natural mortality to be inversely scaled to fish length, which may help explain the different NBSs observed in this study: an assemblage dominated by smaller sizes will have higher mortality rates and hence will lose biomass faster, leading to steeper NBSs.

The slopes of the NBSs were related to productivity in the area. In the most productive areas (upwelling centres), the abundance of the smallest size classes was extremely high and the biomass clearly decreased with size. In the less productive areas with lower abundance of the smaller size classes (lower slope), the trend was distinctly different, with biomass tending to increase or at least remain constant over the size spectrum. This pattern is clearly evidenced by the contribution to the total biomass of each size class in the different assemblages (Fig. 1). Similar relationships between slope and productivity have been reported by other researchers (Ahrens \& Peters 1991, Rasmussen 1993), though Sprules \& Munawar (1986) did not find
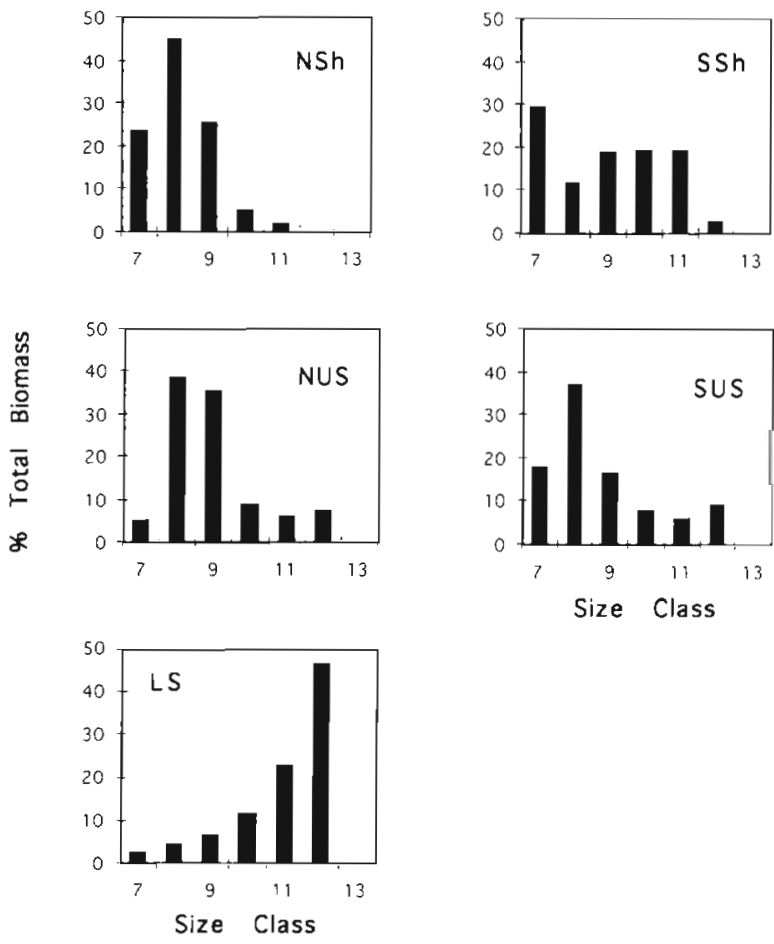

Fig. 1. Percentage of total biomass ( $y$-axis) by size-class ( $x$ axis) for benthic fish assemblages in winter 1988. The size classes correspond to the $\log _{2}$ of weight (numerals indicate the upper boundary of each class). Assemblages: NSh = northern shelf; NUS = northern upper slope; $S S h=$ southern shelf; SUS $=$ southern upper slope; $\mathrm{LS}=$ lower slope 
any such relationship. Comparison of our results with the few other studies carried out on fish assemblages (Haedrich 1986, Haedrich \& Merret 1992) is rather difficult, because different methods of data collection and analysis have been used. Nevertheless, those studies also suggested that differences recorded in the biomass spectra were the result of differences in energy inputs into the system. The observed pattern in Namibia, which spans eutrophic and oligotrophic areas in which the slopes of the NBSs change from steeper than -1 to shallower than -1 , may constitute a general pattern that needs to be examined in other regions with different productivity levels

The findings reported here are consistent with the predictions of ecological theory (e.g. Margalef 1974, 1981, Hutchinson 1978). Biomass distributions characterize the different ecosystems since they are related to the stability and turnover rates of those systems, such that a flatter spectrum with a larger fraction of the biomass distributed in segments with slow turnover rates (e.g. larger size classes, small numbers of offspring subject to low vulnerability rates, slow growth rates) corresponds to higher levels of diversity and stability. Conversely, small size classes with fast turnover rates and low levels of diversity are characteristic of more productive areas. Off Namibia, the data indicate that in eutrophic areas community production is dominated by small individuals, presumably with high turnover rates. Those areas are likewise characterized by a predominance of mid-trophic-level predators (e.g. predators of euphausiids and other pelagic crustaceans). This pattern changes in oligotrophic areas (e.g. the lower slope), in which the abundance of larger individuals increases, with a prevalence of species that probably have slower turnover rates located at the apex of the food chain (e.g. predators of cephalopods and fishes). Elasmobranchs, which do in fact have very low reproductive rates and low vulnerability of eggs and juveniles (e.g. Merret 1994), are the most abundant species. Similarly, certain members of the most abundant species of teleost fishes on the lower slope have extremely slow growth rates (e.g. Smith et al. 1995, Stewart et al. 1995), unlike the predominant species on the shelf (Crawford et al. 1987 and references therein).

Analyses of biological systems from the standpoint of size distributions are obviously of great ecological interest, and some workers have suggested applying such analyses for measuring both the level of stress in a given area (e.g. Warwick 1986, Schwinghammer 1988, Warwick \& Clarke 1994) and fish production (e.g. Keer \& Neal 1976, Sheldon et al. 1977, Mann 1982, Moloney \& Field 1985, Sprules et al. 1991, Sprules \& Goyke 1994). Some work has been based on the assumption that biomass distributions are uniform across all size classes, but exceptions to the flat spectrum are known to occur (Sheldon et al. 1972, Peters 1983), as the present study has confirmed. For this reason, great care must be taken when drawing generalizations based on practical applications of biomass spectra to different cases, especially when productivity in a region is highly heterogeneous, as it is off Namibia.

Acknowledgements. We thank all the participants of the BENGUELA cruises for their invaluable help in collecting data. We gratefully acknowledge B. Moli for her help in processing data. This manuscript benefited from the numerous comments from $Y$ Prairie and the text revision made by $R$. Sacks

\section{LITERATURE CITED}

Ahrens M, Peters RH (1991) Patterns and limitations in limnoplankton size spectra. Can J Fish Aquat Sci 48:1967-1978

Cattaneo A (1993) Size spectra of benthic communities in Laurentian streams. Can J Fish Aquat Sci 50:2659-2666

Chapman P. Shannon LV (1985) The Benguela ecosystem 2. Chemistry and related processes. In: Barnes $M$ (ed) Oceanography and marine biology. An annual review, 23. University Press, Aberdeen, p 183-251

Crawford RJM, Shannon LV, Pollock DE (1987) The Benguela ecosystem 4. The major fish and invertebrate resources In: Barnes $M$ (ed) Oceanography and marine biology. An annual review, 25. University Press, Aberdeen, p 353-505

Doubleday WG, Rivard D (1981) Bottom trawl surveys. Can Spec Publ Fish Aquat Sci 58:941-949

Estrada M, Marrase C (1987) Phytoplankton biomass and productivity off the Namibian coast. In: Payne AIL, Gulland JA, Brink KH (eds) The Benguela and comparable ecosystems. S Afr J Mar Sci 5:347-356

Gaedke U (1992) The size distribution of plankton biomass in a large lake and its seasonal variability. Limnol Oceanogr 37:1202-1220

Gordoa A, Duarte CM (1992) Size-dependent density of the demersal fish off Namibia: patterns within and among species. Can J Fish Aquat Sci 49:1990-1993

Gordoa A, Macpherson E, Olivar MP (1995) Biology and fisheries of Namibian hakes ( $M$. paradoxus and $M$. capensis). In: Alheit J, Pitcher TJ (eds) Hake: biology, fisheries and markets. Chapman \& Hall, London, p 49-88

Haedrich RL (1986) Size spectra in mesopelagic fish assemblages. In: Pierrot-Bults $\mathrm{AC}$, van der Spoel S, Zahuranec BJ, Johnson RK (eds) Pelagic biogeography. UNESCO Tech Pap Mar Sci 49:107-111

Haedrich RL, Merrett NR (1992) Production/biomass ratios, size frequencies, and biomass spectra in deep-sea demersal fishes. In: Rowe GT, Pariente V (eds) Deep-sea food chain and the global carbon cycle. Kluwer, Dordrecht, p $157-182$

Hutchinson GE (1978) An introduction to population ecology. Yale University Press, London.

Kerr SR, Neal MW (1976) Analysis of large-scale ecological systems. J Fish Res Bd Can 33:2083-2089

Macpherson E (1989) Influence of geographical distribution, body size and diet on population density of benthic fishes off Namibia (South West Africa). Mar Ecol Prog Ser 50: 295-299

Macpherson E, Gordoa A (1992) Trends in the demersal fish community off Namibia from 1983 to 1990. In: Payne AIL, Brink KH, Mann KH, Hilborn R (eds) Benguela trophic functionings. S Afr J Mar Sci 12:635-649 
Mann KH (1982) Ecology of coastal waters. A systems approach (Studies in ecology 8). Blackwell, Oxford

Margalef R (1974) Ecologia. Omega, Barcelona

Margalef R (1981) La biosfera entre la termodinámica y el juego. Omega, Barcelona

Mas-Riera J, Lombarte A, Gordoa A, Macpherson E (1990) Influence of Benguela upwelling on the structure of demersal fish populations off Namibia. Mar Biol 104: $175-182$

Merrett NR (1994) Reproduction in the North Atlantic oceanic ichthyofauna and the relationship between fecundity and species' sizes. Environ Biol Fishes 41:207-245

Moloney CL, Field JG (1985) Use of particle-size data to predict potential pelagic-fish yields of some southern African areas. S Afr J Mar Sci 3:119-128

Payne AIL, Augustyn CJ, Leshe RW (1985) Biomass index and catch of Cape hake from random stratified sampling cruises in Division 1.6 during 1984. Collect Sci Pap Int Commn SE Atl Fish 12:99-123

Peters RH (1983) The ecological implications of body size. Cambridge University Press, Cambridge

Platt T, Denman K (1978) The structure of pelagic marine ecosystems. Rapp Pv Réun Cons Int Explor Mer 173: $60-65$

Quiñones RA (1994) A comment on the use of allometry in the study of pelagic ecosystem processes. In: Rodriguez J, Li WKW (eds) The size structure and metabolism of the pelagic ecosystem. Sci Mar 58:11-16

Rasmussen JB (1993) Patterns in the size structure of littora] zone macroinvertebrate communities. Can J Fish Aquat Sci 50:2192-2207

Rodhouse PG, Piatkowski U, Murphy EJ, White MG, Bone DG (1994) Utility and limits of biomass spectra: the nekton community sampled with the RMT 25 in the Scotia Sea during austral summer. Mar Ecol Prog Ser 112:29-39

Rodriguez J (1994) Some comments on the size-based structural analysis of the pelagic ecosystem. In: Rodriguez $\mathrm{J}, \mathrm{Li}$ WKW (eds) The size structure and metabolism of the pelagic ecosystem. Sci Mar 58:1-10

Rodriguez J, Mullin MM (1986) Relation between biomass and body weight of plankton in a steady state oceanic cosystem. Limnol Oceanogr 31:361-370

Rojo C, Rodriguez J (1994) Seasonal variability of phytoplankton size structure in a hypertrophic lake. J Plankton Res 16:317-335

Schwinghamer P (1981) Characteristic size distributions of integral benthic communities. Can J Fish Aquat Sci 38 : $1255-1263$

This article was submitted to the editor
Schwinghamer P (1988) Influence of pollution along a natural gradient and un a mesocosm experiment on biomass-size spectra of benthic communities. Mar Ecol Prog Ser 46 : $199-206$

Shannon LV (1985) The Benguela ecosystem 1 Evolution of the Benguela, physical features and processes. In: Barnes $M$ (ed) Oceanography and marine blology. An annual review, 23. University Press, Aberdeen, p 105-182

Sheldon RW, Prakash A, Sutcliffe WH (1972) The size distribution of particles in the ocean. Limnol Oceanogr 17:327-340

Sheldon RW, Sutcliffe WH, Paranjape MA (1977) Structure of pelagic food chain and relationship between plankton and fish production. J Fish Res Bd Can 34:2344-2353

Smith DC, Fenton GE, Robertson SG, Short SA (1995) Age determination and growth of orange roughy (Hoplostethus atlanticus): a comparison of annulus counts with radiometric ageing. Can J Fish Aquat Sci 52:391-401

Sprules WG, Brandt SB, Stewart DJ, Munawar $M$, Jin EH, Love J (1991) Biomass size spectrum of the Lake Michigan pelagic food web. Can J Fish Aquat Sci 48:105-115

Sprules WG, Goyke AP (1994) Size-based structure and production in the pelagia of Lakes Ontario and Michigan Can J Fish Aquat Sci 51:2603-2611

Sprules WG, Munawar M (1986) Plankton size spectra in relation to ecosystem productivity, size and perturbation. Can J Fish Aquat Sci 43:1789-1794

Stewart BD, Fenton GE, Smith DC, Short SA (1995) Validation of otolith-increment age estimates for a deepwater fish species, the warty oreo, Allocyttus verrucosus, by radiometric analysis. Mar Biol 123:29-38

Thiebaux ML, Dickie LM (1993) Structure of the body-size spectrum of the biomass in aquatic ecosystems: a consequence of allometry in predator-prey interactions. Can J Fish Aquat Sci 50:1308-1317

Thurston MH, Bett BJ, Rice AL, Jackson PAB (1994) Variations in the invertebrate abyssal megafauna in the North Atlantic Ocean. Deep Sea Res 41:1321-1348

Turon JM (1986) Contribución al conocimiento de la ictiofauna del Atlántico Sudoriental (Banco de Valdivia y costa de Namibia). PhD thesis, University of Barcelona

Warwick RM (1984) Species size distribution in marine benthic communities. Oecologia 61:32-41

Warwick RM (1986) A new method for detecting pollution effects on marine macrobenthic communities. Mar Biol 92:557-562

Warwick RM, Clarke KR (1994) Relearning the ABC: taxonomic changes and abundance/biomass relationships in disturbed benthic communities. Mar Biol 118:739-744

Manuscript first received: December 29, 1995

Revised version accepted: April 3, 1996 